\title{
Infection of army ant pupae by two new parasitoid mites (Mesostigmata: Uropodina)
}

\author{
Adrian Brückner ${ }^{\text {Corresp., }}{ }^{1}$, Hans Klompen ${ }^{2}$, Andrew Iain Bruce ${ }^{3}$, Rosli Hashim ${ }^{4}$, Christoph von Beeren ${ }^{1}$ \\ ${ }^{1}$ Ecological Networks, Department of Biology, Technische Universität Darmstadt, Darmstadt, Germany \\ 2 Department of Evolution, Ecology and Organismal Biology, Ohio State University, Columbus, Ohio, United States \\ 3 School of Biological Sciences, Monash University, Melbourne VIC, Australia \\ 4 Institute of Biological Sciences, Faculty of Science Building, University of Malaya, Kuala Lumpur, Malaysia \\ Corresponding Author: Adrian Brückner \\ Email address: adrian.brueckner@gmail.com
}

A great variety of parasites and parasitoids exploit ant societies. Among them are the Mesostigmata mites, a particularly common and diverse group of ant-associated arthropods. While parasitism is ubiquitous in Mesostigmata, parasitoidism has only been described in the genus Macrodinychus. Yet, information about the basic biology of most Macrodinychus species is lacking. Out of 24 formally described species, information about basic life-history traits is only available for three species. Here we formally describe two new Macrodinychus species, i.e. Macrodinychus hilpertae and Macrodinychus derbyensis. In both species, immature stages developed as ecto-parasitoids on ant pupae of the SouthEast Asian army ant Leptogenys distinguenda. By piercing the developing ant with their chelicera, the mites apparently sucked ant hemolymph, ultimately killing host individuals. We compare infection rates among all studied Macrodinychus species and discuss possible host countermeasures against parasitoidism. The cryptic lifestyle of living inside ant nests has certainly hampered the scientific discovery of Macrodinychus mites and we expect that many more macrodinychid species await scientific discovery and description. 
1 Title page

\section{Infection of army ant pupae by two new parasitoid mites}

\section{3 (Mesostigmata: Uropodina)}

4 Authors:

5 Adrian Brückner ${ }^{*}$, Hans Klompen², Andrew Iain Bruce ${ }^{3}$, Rosli Hashim4, and 6 Christoph von Beeren ${ }^{1}$

$7{ }^{1}$ Ecological Networks, Department of Biology, Technische Universität Darmstadt, 64287 Darmstadt,

8 Germany

$9{ }^{2}$ Department of Evolution, Ecology and Organismal Biology, Ohio State University, Columbus OH 43212,

10 USA

$11{ }^{3}$ School of Biological Sciences, Monash University, Melbourne VIC 3800, Australia

$12{ }^{4}$ Institute of Biological Sciences, Faculty of Science Building, University of Malaya, 50603 Kuala 13 Lumpur, Malaysia

$14 *$ Corresponding author:

15 e-mail: adrian.brueckner@googlemail.com 


\section{Abstract}

17 A great variety of parasites and parasitoids exploit ant societies. Among them are the

18 Mesostigmata mites, a particularly common and diverse group of ant-associated arthropods.

19 While parasitism is ubiquitous in Mesostigmata, parasitoidism has only been described in the

20 genus Macrodinychus. Yet, information about the basic biology of most Macrodinychus species is

21 lacking. Out of 24 formally described species, information about basic life-history traits is only

22 available for three species. Here we formally describe two new Macrodinychus species, i.e.

23 Macrodinychus hilpertae and Macrodinychus derbyensis. In both species, immature stages

24 developed as ecto-parasitoids on ant pupae of the South-East Asian army ant Leptogenys

25 distinguenda. By piercing the developing ant with their chelicera, the mites apparently sucked ant

26 hemolymph, ultimately killing host individuals. We compare infection rates among all studied

27 Macrodinychus species and discuss possible host countermeasures against parasitoidism. The

28 cryptic lifestyle of living inside ant nests has certainly hampered the scientific discovery of

29 Macrodinychus mites and we expect that many more macrodinychid species await scientific

30 discovery and description. 


\section{Background}

32 In 1982 David H. Kistner published an influential book chapter with the title "The Social Insects'

33 Bestiary" (Kistner, 1982), a metaphor referring to the many thousand arthropod species

34 exploiting social insect societies (Kistner, 1979, 1982; Hölldobler \& Wilson, 1990). Among them

35 are such diverse groups as beetles, flies, wasps, ants, millipedes, silverfish, and mites

36 (Donisthorpe, 1927; Rettenmeyer, 1961; Kistner, 1979, 1982; Hölldobler \& Wilson, 1990;

37 Buschinger, 2009; Parker, 2016). The latter are particularly abundant guests of social insect

38 colonies (Kistner, 1982; Eickwort, 1990; Gotwald Jr, 1996). The mite order Mesostigmata is

39 notable in this respect because 20 out of 109 of its families are considered to have some kind of

40 relationship with ants (Walter \& Proctor, 1999; Beaulieu et al., 2011). While most of the

41 myrmecophilous mites use ant workers solely as transportation vehicles, some species are

42 ectoparasitic (Kistner, 1982; Eickwort, 1990). For instance, Macrocheles rettenmeyeri Krantz,

431962 (Mesostigmata: Macrochelidae) is an ectoparasite of Neotropical army ants (Eickwort,

44 1990). This 'myrmecophile' (ant lover) specifically attaches to the pulvilli of Eciton dulcium

45 Forel, 1912 legs (Krantz, 1962; Gotwald Jr, 1996), where it probably sucks hemolymph from the

46 ants' arolium, an adhesive organ at the tip of legs enabling ants to climb smooth or steep surfaces

47 (Hölldobler \& Wilson, 1990). While the negative impact of this ectoparasitic myrmecophile on

48 host fitness is supposedly small, some of the ant-associated mites are parasitoids (Lachaud,

49 Klompen \& Pérez-Lachaud, 2016) and therefore, by definition (Godfray, 1994, 2004), kill host

50 individuals.

51 Given the great diversity of mite myrmecophiles, it is surprising that a parasitoid lifestyle is only

52 known in a single mite family, i.e. the Macrodinychidae (Mesostigmata) (González, Gómez \&

53 Mesa, 2004; Breton, Takaku \& Tsuji, 2006; Krantz, Gómez \& González, 2007; Lachaud,

54 Klompen \& Pérez-Lachaud, 2016). In the most recent revisions of the group, the family’s only 
55 genus, Macrodinychus Berlese, 1917, contained 24 valid species which are distributed throughout

56 tropical regions and some temperate regions (Kontschán, 2011, 2017). Information about the

57 basic biology and life history of most Macrodinychus species is lacking. The life cycle is only

58 well known for three out of 24 species, i.e. M. sellnicki Hirschmann \& Zirngiebl-Nicol, 1975

59 (González, Gómez \& Mesa, 2004; Krantz, Gómez \& González, 2007), M. multispinosus Sellnick,

601973 (Lachaud, Klompen \& Pérez-Lachaud, 2016), and Macrodinychus yonakuniensis

61 Hiramatsu, 1979 (Breton, Takaku \& Tsuji, 2006). These species develop on ant pupae where

62 immatures suck the host's hemolymph to an extent that is lethal to the ants (Lachaud, Klompen \&

63 Pérez-Lachaud, 2016). In 1975, Werner Hirschmann, a pioneer in the taxonomy of Uropodina,

64 i.e. an infraorder within the order Mesostigmata (Beaulieu et al., 2011), hypothesized that all

65 Macrodinychus species are parasites of ants (Hirschmann, 1975):

66 „Bei den Bodenfunden von Macrodinychus-Arten [...] handelt es sich wohl um einzelne

67 Zufallsfunde; denn der eigentliche Lebensraum der Macrodinychus-Arten scheint das

68 Ameisennest zu sein, wo die Tiere als Paraphagen oder Parasiten an Ameisen leben dürften. “

69 (Translation: The Macrodinychus species [...] collected from soil samples are probably chance

70 finds, because the actual living environment of the Macrodinychus species seems to be the ant

71 nest, where the animals live as paraphages or parasites on ants.)

72 When Hirschmann wrote these lines, his hypothesis was speculative and lacked solid evidence.

73 For most Macrodinychus species we still lack information about their basic biology including

74 possible symbiosis with ants. Today it is known that about one third of the Macrodinychus

75 species are indeed associated with ants, with three definite examples of parasitoidism (Lachaud,

76 Klompen \& Pérez-Lachaud, 2016). In the present study, we provide further support for

77 Hirschmann's hypothesis by adding two additional species to the list of Macrodinychus

78 parasitoids. We formally describe and provide life history information for two hitherto 
79 undescribed Macrodinychus species, Macrodinychus hilpertae Brückner, Klompen \& von Beeren

80 sp. nov. and Macrodinychus derbyensis Brückner, Klompen \& von Beeren sp. nov. Both species

81 were collected from colonies of the South-East Asian army ant Leptogenys distinguenda. Like

82 other Macrodinychus parasitoids, the entire juvenile development of the new species took place

83 as ecto-parasitoids on host pupae, ultimately killing the host individuals.

\section{Materials \& Methods}

\section{Collection and specimen depository}

86 Two Macrodinychus (Mesostigmata: Uropodina) species were discovered during a project aiming

87 to uncover the interactions of the army ant Leptogenys distinguenda and its diverse

88 myrmecophile fauna (Witte et al., 1999, 2002; Kistner, Witte \& Maschwitz, 2003; Witte et al.,

89 2008; Maruyama, von Beeren \& Hashim, 2010; Maruyama, von Beeren \& Witte, 2010; Mendes,

90 von Beeren \& Witte, 2011; Ott et al., 2015). The mites were initially hidden, enclosed in ant

91 pupal cocoons, and collection took place incidentally by collecting ant pupae (Fig. 1). The latter

92 were collected during army ant colony emigrations using aspirators and forceps [for more

93 information see (von Beeren et al., 2011b)]. Collection took place in Malaysia, primarily at the

94 Ulu Gombak Field Studies Centre of the University Malaya (latitude: 3.325, longitude: 101.750,

95 elevation: 260) and additionally at the Biodiversity Institute Bukit Rengit (latitude: 3.596,

96 longitude: 102.182, elevation: 72), between April and May 2008, August and September 2008,

97 February and March 2009, August and September 2009, February and March 2010, and March

98 and April 2011 (approx. 11 months in total). The specimens were stored in absolute ethanol and

99 deposited at the Ohio State University Acarology Collection, Columbus, Ohio, USA (OSAL).

100 Macrodinychid mites are vouchered together with their respective ant pupa. Further specimens are

101 deposited at the Adam Mickiewicz University in Poznań (three specimens of M. hilpertae labeled

102 as "Tank mite" and two specimens of M. derbyensis labeled as "Smooth shell"). Borrowing the 
103 latter specimens for morphological analysis was not possible in a reasonable time frame, because

104 of an entire re-organisation of the department's mite collection. All other specimens have been

105 lost during several institutional moves of one of the authors (CvB).

106 Note that the host ant is an undescribed species (personal communication, Kouichi Arimoto). It

107 was designated previously as Leptogenys sp. 1 (Maschwitz et al., 1987, 1989) and as $L$.

108 distinguenda (see Maschwitz \& Steghaus-Kovac, 1991; Witte \& Maschwitz, 2000, 2002; Witte et 109 al., 2008; von Beeren et al., 2011a). To be consistent with the most recent publications we use the 110 name Leptogenys distinguenda for the species, which is in fact a nomen nudum. Specimen images

111 of L. distinguenda have been published previously (denoted there as L. distinguenda (Maruyama,

112 von Beeren \& Hashim, 2010)). Voucher ant specimens are deposited at the Southwest Forestry

113 University Ant Collection, Kunming, Yunnan Province, China (collection identifiers: A11-5936 114 A11-5942).

115 The electronic version of this article in Portable Document Format (PDF) will represent a 116 published work according to the International Commission on Zoological Nomenclature (ICZN), 117 and hence the new names contained in the electronic version are effectively published under that 118 Code from the electronic edition alone. This published work and the nomenclatural acts it 119 contains have been registered in ZooBank, the online registration system for the ICZN. The

120 ZooBank LSIDs (Life Science Identifiers) can be resolved and the associated information viewed 121 through any standard web browser by appending the LSID to the prefix http://zoobank.org/. The 122 LSID for this publication is: urn:Isid:zoobank.org:pub:84ADDB13-56F3-431D-9244-

123 E19C3A2F7E04. The online version of this work is archived and available from the following 124 digital repositories: PeerJ, PubMed Central and CLOCKSS. 


\section{Prevalence of mites}

126 To evaluate mite prevalence and screen for different development stages we gently opened a total

127 of 2,360 L. distinguenda pupal cocoons from a total of six different colonies. Since many adult

128 specimens found during these dissections have been lost, we were not able to reliably identify all

129 Macrodinychus specimens to the species level. As a consequence of this, we could not determine

130 the prevalence for each of the two species separately, but instead evaluated the overall parasitism

131 rate among Macrodinychus spp., i.e. the total number of pupal infections by Macrodinychus

132 mites. In addition, after an initial screening of 1,391 pupal cocoons for adult Macrodinychus

133 mites in 2009 and 2010, all L. distinguenda pupae from different colonies were combined in 2012

134 for storage at the LMU Munich. Therefore, we only have limited data about the colony of origin

135 of Macrodinychus mites.

136 For three additional $L$. distinguenda colonies we estimated the total number of pupae allowing us

137 to estimate the number of pupal infections per colony. For this, Leptogenys bivouac sites were

138 marked with tape and checked every 30 min for ongoing colony emigrations. Upon the start of an

139 emigration, defined as workers carrying larvae or pupae to the new nest site, the number of

140 Leptogenys workers carrying pupae and heading toward the new bivouac site was repeatedly

141 counted for $30 \mathrm{sec}$, followed by a $150 \mathrm{sec}$ break till the emigration was finished. We did not

142 collect pupae for dissections from these colonies.

\section{Morphological protocol and imaging}

144 Specimens were dissected and slide mounted in Hoyer's medium or lactophenol (Walter \&

145 Krantz, 2009) and studied with bright-field and phase contrast microcopy. Morphological

146 structures were drawn based on images taken during the phase contrast microscopy. In addition,

147 focus-stacked images were taken with a Keyence VHX-5000 digital microscope (Keyence

148 Deutschland GmbH, Neu-Isenburg, Germany) using the VH-Z50L lens. All measurements were 
149 taken using internal scale function as implemented in the Keyence system software (version

150 1.5.1.1; system version 1.0.4). A total of 37 images were uploaded to the Barcode of Life

151 Database. Images can be accessed using the sample ID (provided in results) as search term.

152 Images of all immature stages can be found on BOLD (search using the sample ID). Holotype

153 label information is listed verbatim, with the different labels separated by forward slashes.

\section{Observations in laboratory nests}

155 Interactions between host ants and adult Macrodinychus specimens were studied in laboratory

156 nests containing 110-170 ant workers, 44-55 ant pupae, 22-30 callows (freshly hatched workers)

157 and three to six clusters of ant larvae. Behavioral tests were carried out with workers of the

158 myrmecophile`s colony of origin. Details about the nest set-ups were described previously (von

159 Beeren et al., 2011a). Myrmecophiles were tested individually. Frequently, myrmecophiles

160 behaved excitedly for a short period after transferring them to laboratory nests, which sometimes

161 initiated ant aggression. To avoid biases caused by the specimen transfer we gave myrmecophiles

162 two minutes settling time before recording the ant behaviors. We then observed the interactions

163 of the myrmecophile in the first 50 consecutive encounters with host ant workers (for definition

164 of behavioral categories see supplementary Table S1). At the study time, we did not realize that

165 there are two different Macrodinychus species and therefore the data presented here cannot be

166 assigned to the species level. Nonetheless, we consider the behavioral data as valuable because

167 behavioral interactions with host ants have not been studied systematically for any

168 Macrodinychus species. To compare the host-symbiont interactions of Macrodinychus spp. with

169 those of other L. distinguenda myrmecophiles, we additionally tested the following associates:

170 the silverfish Malayatelura ponerophila Mendes, von Beeren \& Witte, 2011 (Mendes, von

171 Beeren \& Witte, 2011), the spider Sicariomorpha maschwitzi Wunderlich, 1995 (Wunderlich,

172 1994), the snail Allopeas myrmecophilos Janssen \& Witte, 2002 (Janssen \& Witte, 2002), and the 
173 rove beetles Maschwitzia ulrichi Kistner, 1989 (Kistner, 1989), Witteia dentrilabrum Maruyama

174 \& von Beeren, 2010 (Maruyama, von Beeren \& Hashim, 2010), and Togpelenys gigantea Kistner,

1751989 (Kistner, 1989). Data on rove beetles were published previously (von Beeren et al., 2011a).

\section{Data analysis}

177 Behavioral counts were expressed as compositional data [\%] by standardizing for the total

178 number of interactions per specimen (approx. 50 interactions per specimen: mean $\pm \mathrm{SD}=50.83 \pm$

1793.20 interactions, $\mathrm{N}=97$ ). These multivariate data were analyzed with a permutational analysis

180 of variance (PERMANOVA) with 9,999 permutations based on Bray-Curtis similarities. Due to

181 the rareness of certain associates, some specimens were tested multiple times (Table S2). This

182 was considered in the PERMANOVA design (Myrmecophile species = fixed factor; Specimen ID

$183=$ random factor). In addition to the multivariate analysis of behavioral interactions, we calculated

184 an aggression index (AI in [\%]) to measure the total aggression of ants towards a focal

185 myrmecophile. For this, the sum of aggressive behaviors (chased, snapped, stung) was divided

186 through the total number of interactions. We applied PERMANOVA for univariate cases based on

187 Euclidean distances with the same design as described above. PERMANOVAs were run with the 188 software Primer 7 (Primer-E Ltd., Ivybridge, U.K., vers. 7.0.12) with the add-on

189 PERMANOVA+1 (Anderson, Gorley \& Clarke, 2008). 
190 Results - Taxonomic Section

191 Species descriptions

192 Infraorder UROPODINA Kramer, 1881

193 Family MACRODINYCHIDAE Kontschán, 2017

194 Genus MACRODINYCHUS Berlese, 1917

195 Systematic note: For this study, we follow the classification of Kontschán $(2011,2017)$ in

196 recognizing a single genus, Macrodinychus Berlese 1916, in the family Macrodinychidae

197 Kontschán 2017. Within this genus four subgenera are recognized (largely corresponding to the

198 “Stadiengattungen” of Hirschmann 1979): Macrodinychus, Monomacrodinychus Hirschmann

1991975 (= Baloghmacrodinychus Hirschmann 1979, see Halliday 2015), Bregetovamacrodinychus

200 Hirschmann 1979, and Loksamacrodinychus Hirschmann 1979. Both of the new species belong

201 in the subgenus Macrodinychus (Monomacrodinychus) based on the shape of the peritremes.

202 Diagnosis of the genus Macrodinychus (based on Kontschán 2011, 2017 and

203 Hirschmann 1975)

204 Within Uropodina, the genus Macrodinychus is characterized by the following characters:

205 Idiosoma large, oval or sometimes oblong, posterior margin rounded, anterior margin sometimes

206 angular. Color yellow-brown to darkish brown. All legs short, but well developed. Tritosternum

207 trifurcate with narrow basis. Gnathosoma with long hypostomal setae, horn-/peanut-like

208 corniculi, pilose internal malae, pilose gnathotectum and chelicera with sclerotized nodes and

209 without processes on tip fixed digit. Gnathosoma usually largely covered by coxae I. Genital

210 shield of females small relative to the body (when compared to other Uropodina) and comparable

211 in size to that of the males. Females and males do not differ in the shape and structure of the

212 peritremes. Potentially viviparous. 
213

214

215

216

217

218

219

220

221

222

223

224

225

226

227

228

229

230

231

232

233

234

235

\section{Macrodinychus (Monomacrodinychus) hilpertae Brückner, Klompen \& von Beeren}

sp. nov.

Type-host: Leptogenys distinguenda (Formicidae: Ponerinae)

Type-locality: Ulu Gombak Field Studies Centre of the University Malaya $\left(03^{\circ} 19.479\right.$ ' N, $101^{\circ} 45.163$ 'E, altitude $230 \mathrm{~m}$ ), Selangor, Malaysia.

Type-specimens: Holotype: female, accession number OSAL 0119286 (Fig. 2), stored in absolute ethanol, field sample code: cvb757macro008, deposited at OSAL. Paratypes: on type host and from type locality: F, OSAL 0100050, 95\% ethanol, cvb800macro002; male, OSAL 0106708, slide, dissected; on type host but from MALAYSIA: Pahang, Bukit Rengit (3.596 N 102.180 E, 72m), F, OSAL 0103942, slide; F, OSAL 0103943, slide; F, OSAL 0103944, slide. All paratypes deposited at OSAL. Other specimens: all on type host from type locality: female, OSAL 0119279, 95\% ethanol, cvb757macro001; 5 deutonymphs, OSAL 0119280-281, 0119283284, 0119290, 95\% ethanol; 5 deutonymphs, OSAL 0102594, 0102596, 0106709-711, slide; 1 protonymph, OSAL $0119282,95 \%$ ethanol.

ZooBank registration: Details of the new species have been submitted to ZooBank to comply with the current regulation of the ICZN. The Life Science Identifier (LSID) of the article is urn:1sid:zoobank.org:pub:84ADDB13-56F3-431D-9244-E19C3A2F7E04. The LSID for the new name Macrodinychus (Monomacrodinychus) hilpertae is urn:1sid:zoobank.org:act:88FADEC7D4A5-4491-A45E-8F8176B65D31.

Etymology: Dedicated to Andrea Hilpert, for her advice, long lasting skillful technical assistance and support of $\mathrm{AB}$ and $\mathrm{CvB}$.

Description: General: Length of the idiosoma $2100 \mu \mathrm{m}$, width $1250 \mu \mathrm{m}$ (holotype). Shape oblong, posterior margin rounded, color darkish brown. 
236 Dorsal (Fig. 2A): Dorsal shield rough with micro-ornamentation and an alveolar pattern.

237 Completely sclerotized, middle part of the dorsal shield pronounced in a characteristic shape

238 (also in lateral view). Dorsum hypertrichous. Dorsal shield covered by distinct and regularly

239 distributed bulbiform setae. Setae covered with additional hairs on their margins. Dorsal and

240 marginal shield not fused anteriorly. Tips of marginal shield not fused anteriorly. Marginal shield

241 with a crenellation-like pattern of alveolae and ridges. Isolated pygidial shield with alveolar

242 patterns, but without setae.

243 Ventral (Fig. 2C): Fused sternal and ventral shields bear an alveolar pattern with further micro-

244 ornamentation on the rest of the cuticle. Female operculum between coxae II-III, length $188 \mu \mathrm{m}$,

245 male operculum round, between coxae III, length $102 \mu \mathrm{m}$. Genital shields in both sexes without

246 ornamentation. Scabellum covered by fish scale-like pattern. All ventral setae bulbiform. Position

247 of sternal setae (St): St 1 and St 2 placed between coxae I and II. St 3 inserted near the posterior

248 margin of coxae II. Setation around the genital shield hypertrichous. An additional row of four

249 pair of setae at the posterior margin of the operculum. Stigmata between coxae II and III,

250 peritreme species-specific with finger-like branches (see supplementary Fig. S1C).

251 Gnathosoma: Gnathotectum triangular, extending in single peak with large barbs (length 190

$252 \mu \mathrm{m})$. Salivary stylets $(105 \mu \mathrm{m})$ long relative to gnathosoma. Subcapitulum: Corniculi peanut-

253 shaped, blunt, length $40 \mu \mathrm{m}$, width $18 \mu \mathrm{m}(\mathrm{N}=2)$. Hypostomal setae long ( $h 1$ 59-62, h2 35-38, h3

254 41-55 $\mu \mathrm{m})$, setiform, barbed; subcapitular (sc) setae rod-shaped, barbed (29-39 $\mu \mathrm{m})$ (generally

255 similar in arrangement and shape as in M. derbyensis, Fig. S1A, but setae shorter). Deutosternum

256 poorly developed with 3 rows of 2 teeth each. Base of the tritosternum cylindrical, vase-like, with

257 a smooth surface. Tritosternum trifurcate, laciniae with fine bristles (Fig. S1D). Chelicera with a

258 distinct "nodus", and lacking a membranous extension on the fixed digit; distal end of fixed and

259 movable digit with a small tooth, creating a bifid impression (Fig. S1E); moveable digit 70-76 
$260 \mu \mathrm{m}$, fixed digit $87 \mu \mathrm{m}$, entire fixed segment $280 \mu \mathrm{m}$ (maximum width $41 \mu \mathrm{m}$ ), basal segment 232

$261 \mu \mathrm{m}(\mathrm{N}=2)$. Palp length $245 \mu \mathrm{m}$, width $42-49 \mu \mathrm{m}(\mathrm{N}=2)$; tibia and tarsus fused, pretarsus in form

262 of 4-tined apotele. Setation trochanter 2, femur 5, genu 4 setae (tibiotarsus not studied);

263 trochanteral seta $v 1$ long, rod-shaped with increasing density of barbs towards tip (190 $\mu \mathrm{m}), v 2$

264 setiform, substantially shorter, with much shorter barbs.

265 Legs: Legs short relative to body: leg I $1050 \mu \mathrm{m}$, leg II $837 \mu \mathrm{m}$, leg III $859 \mu \mathrm{m}$, leg IV $950 \mu \mathrm{m}$.

266 Note that the measurements provided here are better treated as approximations as the legs were

267 folded into the pedofossae during measurements. Femora I-IV with small posterior flange. Leg

268 setae long and barbed. Chaetotaxy (leg setation formula's following Evans 1963, 1972): coxae 2-

269 2-2-1; trochanters 4-5-5-5; femora 1 4/3 1, 1 4/2 1, $13 / 2$ 0, $13 / 2$ 0; genua $12 / 1$ 2/1 1, $12 / 12 / 1$,

$270 \quad 1$ 2/1 2/0 1, 1 2/1 2/0 1; tibiae 1 1/1 2/1 1, 1 1/1 2/1 1, 1 1/1 2/1 1, 1 1/1 2/1 1, tarsi II-IV 18 setae.

271 Dorsal setae, especially on tibiae and genua, much shorter than lateral or ventral setae

272 (measurements from single individual): on leg I tibia, respectively, $37 \mu \mathrm{m}, 111 \mu \mathrm{m}$ and $219 \mu \mathrm{m}$,

$273 \operatorname{leg}$ II $45 \mu \mathrm{m}, 75 \mu \mathrm{m}, 123 \mu \mathrm{m}$; on genu leg I, respectively, $37 \mu \mathrm{m}, 81 \mu \mathrm{m}, 134 \mu \mathrm{m}$, leg II $50 \mu \mathrm{m}$,

$27474 \mu \mathrm{m}, 93 \mu \mathrm{m}$. Setae ad4 and al4 on basitarsus IV long, well-developed, pd4 and pl4 much

275 shorter and less barbed. Similar difference, though less pronounced, on other segments. Pretarsi

276 of legs I small with a well-developed claw. Pretarsi of legs II - IV with long stalk, small

277 pulvillus, and two claws.

278 Immatures: Larvae unknown. One protonymph, not studied. Deutonymphs weakly sclerotized.

279 Dorsal cuticle distinctly ornamented, mid-dorsal setae distinctly shorter than marginal dorsal

280 setae. Ventral setae generally short $(30-40 \mu \mathrm{m})$, longer near the body margin. All sternal setae

281 relatively short, $S t 4$ also short relative to $S t 1-3(26 \mu \mathrm{m}$ vs. $70 \mu \mathrm{m}, \mathrm{N}=2)$. Gnathosoma unclear in

282 all available specimens. Chelicera with reduced, though distinct, fixed digit $(\sim 1 / 2$ as long as 
283 movable digit). Leg chaetotaxy as in adults except for femur I which carried 2 ventral setae (3

284 ventral setae in adults); tibia IV lacking seta $p d 1$. Legs I with small ambulacrum carrying claws.

285 Differential diagnosis: Within the genus Macrodinychus, this species can be distinguished from

286 most others by its bulbiform setae. This character is only shared with M. extremicus (Kontschán

287 2011), for which it was mistakenly identified in a previous publication (Lachaud, Klompen \&

288 Pérez-Lachaud, 2016). However, M. hilpertae can be unambiguously discriminated from $M$.

289 extremicus by the following characters (for images of the M. extremicus holotype see

290 Supplemental Fig. S2): Most prominently, species differ in the shape of their peritremes and the

291 lateral shape of the dorsal shield (also clearly visible from the dorsal view as ring-like cavities).

292 While M. extremicus has an undulating lateral shape of the dorsal shield with three mounds (Fig.

293 S2), M. hilpertae possess just one mound without any subdivision (compare Figs. 2A and S2A).

294 In addition, M. hilpertae has a highly structured micro-ornamentation on the dorsal shield in

295 contrast to M. extremicus (Fig. 2A and B). Alveolae on dorsal shield are bigger in M. hilpertae.

296 Bulbiform setae are slenderer in M. hilpertae and distributed more evenly on the dorsal shield,

297 while the setae are flap-like in M. extremicus, and are condensed at certain areas of the dorsal

298 shield (supplementary Fig. S2), and are sometimes overlapping.

299 The nymphs of $M$. hilpertae differ substantially from those previously described from $M$.

300 (Macrodinychus) sellnicki or M. (Bregetovamacrodinychus) multispinosus. In both of those

301 species, nymphs have highly regressed idiosomal and leg setation, lacking nearly all idiosomal

302 and non-tarsal leg setae. They also show highly reduced chelicera with fixed digits completely

303 absent [(Krantz, Gómez \& González, 2007); personal observation HK].

304 Macrodinychus (Monomacrodinychus) derbyensis Brückner, Klompen \& von Beeren

305 sp. nov.

306 Type-host: Leptogenys distinguenda (Formicidae: Ponerinae) 
307 Type-locality: Ulu Gombak Field Studies Centre of the University Malaya $\left(03^{\circ} 19.479^{\prime} \mathrm{N}\right.$,

$308101^{\circ} 45.163^{\prime}$ E, altitude $230 \mathrm{~m}$ ), Selangor, Malaysia.

309 Type-specimens: Holotype: female, accession number OSAL 0119286 (Fig. 3), stored in

310 absolute ethanol, field sample code: cvb757macro009, deposited at OSAL. Paratypes: On type

311 host from type locality: male, OSAL 0106707, slide dissected; female, OSAL 0119292,

312 cvb800macro001. Other specimens. On type host from type locality: 3 deutonymphs, OSAL

313 0119285, 0119288-289, 95\% ethanol; 4 deutonymphs, OSAL 0102593, 0103953-955, slide; 1

314 protonymph, OSAL 0119291, 95\% ethanol, cvb757macro013; 1 protonymph, OSAL 0102595,

315 slide. All specimens deposited at OSAL

316 ZooBank registration: Details of the new species have been submitted to ZooBank to comply

317 with the current regulation of the ICZN. The Life Science Identifier (LSID) of the article is

318 urn:lsid:zoobank.org:pub:84ADDB13-56F3-431D-9244-E19C3A2F7E04. The LSID for the new

319 name Macrodinychus (Monomacrodinychus) derbyensis is urn:lsid:zoobank.org:act:83C74026-

320 EF1F-41A8-915F-49B0B2188E2A.

321 Etymology: The name of the new species refers to the fact that both new species (M. hilpertae

322 and $M$. derbyensis) co-occur in the same host species. We further picked this name to honor one

323 of the most diversity-loving, integrative and awesome sports - roller derby - with all its players,

324 flamingos, zebras and enthusiastic supporters.

325 Description: General: Length of the idiosoma $2370 \mu \mathrm{m}$, width $1480 \mu \mathrm{m}$ (holotype). Shape

326 oblong, anterior and posterior margins rounded, color ocher-brown/ brown.

327 Dorsal (Fig. 3A): Dorsal shield completely sclerotized and smooth without ornamentation, but

328 with deep alveolae in the middle part of the dorsal shield. Dorsal shield covered by distinct and

329 regularly distributed smooth, needle-like setae. Setation hypertrichous. Dorsal and marginal 
330 shield not fused anteriorly. Tips of marginal shield not clearly distinct anteriorly and sub-marginal

331 shield apically fused with marginal shield. Marginal shield with a crenellation-like pattern

332 posterior, no pattern medial and an alveolar pattern anterior. Isolated pygidial shield with eight

333 setae and deep pits.

334 Ventral (Fig. 3C): Ventral shield posterior smooth without ornamentation and covered with setae,

335 but ventral shield anteriorly covered with a fine structured micro-alveolar pattern without setae

336 (starting at the peritremes). Sternal and ventral shield fused. Cuticle posterior to genital shield

337 between coxae III and IV with deep pit-like ornamentation. Female operculum between coxae II-

338 III, length $196 \mu \mathrm{m}$, male operculum round, between coxae III, length $140 \mu \mathrm{m}$. Genital shields in

339 both sexes without ornamentation. Scabellum covered by a fine ornamentation. All ventral setae

340 smooth and needle-like. Only two pairs of sternal setae (St1 and St2) clearly distinct from a row

341 of setae along the endopodal line, and rows of additional pairs of setae at the posterior margin of

342 the operculum. Position of sternal setae $(S t)$ : St 1 placed between coxae I and II. St 2 inserted near

343 the anterior margin of coxae II. Stigmata between coxae II and III, peritreme species-specific

344 with finger-like branches (Fig. 3B; supplementary Fig. S1B).

345 Gnathosoma: Gnathotectum triangular, extending in single peak with strong barbs (length 254

$346 \mu \mathrm{m})$. Salivary stylets thick and long $(236 \mu \mathrm{m})$. Subcapitulum (Fig. S1A): Corniculi peanut-

347 shaped, blunt, length $61 \mu \mathrm{m}$, width $22 \mu \mathrm{m}(\mathrm{N}=2)$. Hypostomal setae long $(h 1101-108 \mu \mathrm{m}, h 2$

348 58-61 $\mu \mathrm{m}, h 391 \mu \mathrm{m})$, setiform, barbed, subcapitular setae shorter (46-48 $\mu \mathrm{m})$, rod-shaped,

349 barbed. Deutosternum poorly developed with 3 rows of 2 teeth each. Chelicera with "nodus",

350 lacking membranous extensions on fixed digit; movable digit $82 \mu \mathrm{m}$, fixed digit $102 \mu \mathrm{m}$, entire

351 fixed segment $390 \mu \mathrm{m}$ (maximum width $46 \mu \mathrm{m}$ ), basal segment $390 \mu \mathrm{m}$. Palp length $310 \mu \mathrm{m}$,

352 width $42-47 \mu \mathrm{m}(\mathrm{N}=2)$; tibia and tarsus fused, pretarsus in form of 4-tined apotele. Setation 
353 trochanter 2, femur 5, genu 4 setae (tibiotarsus not studied); trochanteral seta $v 1$ rod-shaped with

354 increasing density of long barbs towards tip (length $124 \mu \mathrm{m}), v 2$ setiform, substantially shorter.

355 Legs: Legs short relative to body: leg I $1184 \mu \mathrm{m}$, leg II $1119 \mu \mathrm{m}$, legs III-IV $1130 \mu \mathrm{m}(\mathrm{N}=1)$.

356 Femora I-IV with small posterior flange. Setal shape and chaetotaxy as in M. hilpertae. Dorsal

357 setae on tibiae and genua much shorter than lateral or ventral setae (measurements from single

358 individual): on leg I tibia, respectively, $59 \mu \mathrm{m}, 192 \mu \mathrm{m}$ and $365 \mu \mathrm{m}$, leg II $45 \mu \mathrm{m}, 75 \mu \mathrm{m}, 123$

$359 \mu \mathrm{m}$; on genu leg I, respectively, $34 \mu \mathrm{m}, 85 \mu \mathrm{m}, 169 \mu \mathrm{m}$, leg II $77 \mu \mathrm{m}$, broken, $154 \mu \mathrm{m}$.

360 Differentiation of setae al4 and $a d 4$ vs. $p d 4$ and pl4 on basitarsus IV distinct, but less so than in

361 M. hilpertae. Pretarsi of legs I small with a single claw. Pretarsi of legs II - IV each with a long

362 stalk, well-developed pulvillus including a pair of setiform structures, and two claws. Pulvillus

363 distinctly larger than in M. hilpertae.

364 Immatures: Larvae unknown. Two protonymphs, not studied. Deutonymphs weakly sclerotized.

365 Dorsal cuticle without distinct ornamentation, mid-dorsal setae as long as marginal dorsal setae.

366 Ventral setae fewer than in M. hilpertae, but longer $(80-95 \mu \mathrm{m})$. Sternal setae long St4 about 2/3

367 the length of $S t 1-3(81 \mu \mathrm{m}$ vs. $128 \mu \mathrm{m}, \mathrm{N}=3)$. Gnathosoma well developed compared to other

368 American macrodinychid species. Chaetotaxy as in adults: $h 141 \mu \mathrm{m}, h 267 \mu \mathrm{m}, h 391 \mu \mathrm{m}, s c 74$

$369 \mu \mathrm{m}(\mathrm{N}=1)$, corniculi peanut-shaped, $28 \times 15 \mu \mathrm{m}$. Chelicera shorter than in adult, fixed digit

370 reduced, but distinct ( $\sim 1 / 2$ length of movable digit). Palps weakly developed, palp apotele

371 present, 3-4-tined. Leg chaetotaxy as in adults but femur I with only 2, rather than 3, ventral

372 setae; ventral setae slightly longer than dorsal ones. Legs I with small ambulacrum carrying 373 claws.

374 Differential diagnosis: Within the genus Macrodinychus, this species can be distinguished from 375 most others by its isolated pygidial shield bearing smooth and needle-like setae. This character is 376 only shared with M. vietnamensis (Hirschmann, 1983), which is the morphologically closest 
377 relative. The holotype of $M$. vietnamensis is lost and not deposited at the Natural History

378 Museum in Budapest, Hungary, as stated in the formal description of the species (Hirschmann,

379 1983). However, we found a slide-mounted specimen designated by Hirschmann as $M$.

380 vietnamensis at the Bavarian State Museum of Zoology. We used this specimen for comparisons

381 (see supplementary Fig. S3). The following characters can be used to discriminate the species:

382 The cuticle of M. derbyensis posterior to genital shield between coxae III and IV possess a deep

383 pit-like ornamentation (Fig. 3C), a character which is absent in M. vietnamensis. Furthermore, the

384 sub-marginal shield of $M$. derbyensis is apically fused with the marginal shield, while the sub-

385 marginal shield is apically distinct from the dorsal shield and the marginal shield in $M$.

386 vietnamensis. In addition, $M$. derbyensis has rows of setae along the endopodal line and

387 additional rows of paired setae at the posterior margin of the operculum, while M. vietnamensis

388 has only five pairs of sternal setae.

389 Descriptions of immature morphology of Macrodinychus are hitherto really limited. Comparing

390 the two species described here, the deutonymphs of $M$. derbyensis differs from those of $M$.

391 hilpertae in relative length of dorsal and ventral setae (especially relative lengths of St4 vs. St1-

392 3), lack of ornamentation of the dorsum, and presence (vs. absence) of seta $p d l$ on tibia IV.

393 Key to species of the subgenus Monomacrodinychus (updated from Kontschán, 2011

394 and 2017)

395 To aid in differentiation of the new species from previously described species, we updated the

396 key to species in the subgenus Monomacrodinychus (Kontschán, 2011, 2017):

1. Peritreme without branches

other subgenera (see Kontschán 2011)

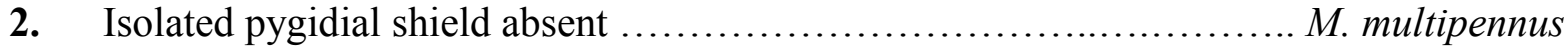

401

Isolated pygidial shield present

3. Dorsal and ventral shields with bulbiform setae .............................. 4

402

Dorsal and ventral shields without bulbiform setae 
403 4. Dorsal shield with rough alveolae without microstructural reticular ornamentation, 404 bulbiform seate big and flap-like, two half ring-form cavities in the central region of the

405

406

407

408

409

410

411

412

413

414

415

416

417

418

419

420

421

422

423

424

425

426

427

428

429

430

431

432 Out of 2,360 inspected L. distinguenda pupae 40 were infected with one of the two

433 Macrodinychus species, i.e. the pupal infection rate at Ulu Gombak was $1.69 \%$. Each pupa was
M. hilpertae

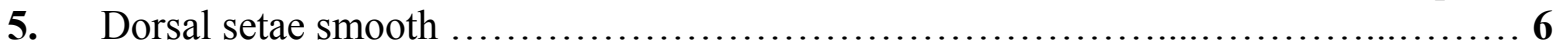

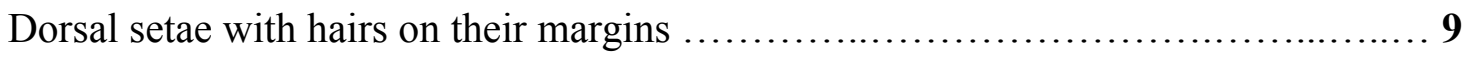

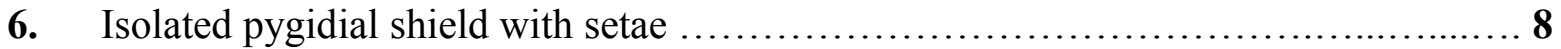

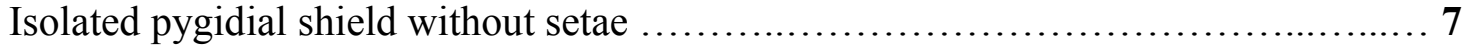

7. Pygidal shield narrow, anterior horns absent................................. kaszabi

Pygdial shield hemispherical, anterior horn present............................ tanduk

8. No rows of setae along endopodal line, five pairs of sternal setae, cuticle posterior to genital shield between coxae III and IV without ornamentation, sub-marginal shield apically distinct form dorsal shield and marginal shield M. vietnamensis Rows of setae along the endopodal line, additional rows of paired setae at the posterior margin of the operculum, only St1 and St2 clearly distinguishable, cuticle posterior to genital shield between coxae III and IV with deep pit-like ornamentation, sub-marginal shield apically fused with marginal shield M. derbyensis

9. Isolated pygidial shield with setae M. shibai Isolated pygidial shield without setae M. yoshidai

10. Apical part of dorsal setae wide and bear short hairs 11

11. Alveolar ornamentation on the lateral part of the dorsal shield, genital shield of female with alveolar pattern M. baloghi Alveolar ornamentation on the whole dorsal shield, genital shield of female without pattern M. hirschmanni

\section{Results - Life History section}

\section{Host infection rate}


434 only infected by a single Macrodinychus specimen. The inspection of host pupae from a single

435 colony in 2009 demonstrated that Macrodinychus species can co-occur in the same colony (M.

436 hilpertae $=2$ infected pupae; $M$. derbyensis $=4$ infected pupae).

437 The pupal number per colony was estimated for three different L. distinguenda colonies: 6456

438 pupae, 5845 pupae, and 9846 pupae. With an infection rate of $1.69 \%$, the total number of pupal

439 infection per colony was estimated to be 109,99 , and 166 , respectively.

\section{Life-history of $M$. hilpertae and $M$. derbyensis}

441 The dissection of 2,360 ant pupae recovered 20 immature and 20 adult mite stages. The following

442 two immature development stages were found: three protonymphs $(M$. derbyensis, $\mathrm{N}=2 ; M$.

443 hilpertae, $\mathrm{N}=1)$ and 17 deutonymphs $(M$. derbyensis, $\mathrm{N}=7 ;$ M. hilpertae, $\mathrm{N}=10)$. All

444 parasitized ant pupae had small, brownish scars (Fig. 4), which were not present in unparasitized

445 ant pupae. Adult mites and deutonymphs that were detached from ant pupae left behind a

446 conspicuous abnormal cavity in pupal bodies (Fig. 4). We did not find Macrodinychus larvae.

447 However, we detected larval exuviae of three M. hilpertae individuals (Fig. 4). Exuviae of proto-

448 and deutonymph were frequently detected inside pupal cocoons, often still attached to the mite or

449 to the ant specimen (e.g., see BOLD image of sample 'cvb757macro002').

\section{Observations in laboratory nests}

451 Myrmecophile species differed in their behavioral interactions with host ants (PERMANOVA, 452 pseudo-F= 37.27, $\mathrm{P}<0.001$; Fig. 5A). Macrodinychus specimens generally walked slowly in the

453 laboratory nests among host workers, which primarily did not notice (mean \pm SD: $24 \pm 10$ events,

$454 \mathrm{~N}=10$ ) or ignored the mites (mean $\pm \mathrm{SD}$ : $18 \pm 8$ events, $\mathrm{N}=10$; Fig. 5). Out of ten behavioral

455 tests, mites were picked up in nine cases by ant workers (see supplementary video). This

456 interaction was initiated by intense antennation by an approaching ant (mean $\pm \mathrm{SD}: 4 \pm 4$ events,

$457 \mathrm{~N}=10$ ). Ants then carried around the mites (mean $\pm \mathrm{SD}: 1 \pm 0$ events, $\mathrm{N}=10$; Table $\mathrm{S} 2$ ), an 
458 interaction uniquely found in Macrodinychus mites and in the snail Allopeas myrmekophilos

459 (Witte et al., 2002). We observed that ants often dumped the mites at the ants` refuse site (see

460 supplementary video).

461 Ant aggression towards separate myrmecophile species differed (PERMANOVA, pseudo-F=

462 15.00, $\mathrm{P}<0.001$; Fig. 5B). Compared to other myrmecophiles of L. distinguenda, ants attacked

463 Macrodinychus mites at a moderate level (mean (AI) \pm SD: $0.08 \pm 0.07, \mathrm{~N}=10$; Fig. 5B). During

464 the $\sim 50$ encounters with host ants, ants chased (mean \pm SD: $0.10 \pm 0.32$ events, $N=10$ ), snapped

465 (mean \pm SD: $2.40 \pm 1.78$ events, $\mathrm{N}=10$ ) and tried to sting the mites (mean $\pm \mathrm{SD}: 2.0 \pm 2.05$

466 events, $\mathrm{N}=10$ ). All Macrodinychus specimens survived the $\sim 50$ encounters with host ants.

\section{Discussion}

\section{Life-history of macrodinychid mites}

469 Adopting Kistner`s metaphor of a social insect bestiary, the two herein described Macrodinychus

470 parasitoids are extraordinary examples of specialized beasts invading ant colonies. Both species

471 fulfill their immature development inside army ant colonies, which constitutes a stable and

472 predator-free space with sufficient supply of food (Kistner, 1979; Hölldobler \& Wilson, 1990;

473 Hughes, Pierce \& Boomsma, 2008). More specifically, Macrodinychus immatures were attached

474 to and most likely fed on defenseless ant pupae.

475 While we do not provide direct evidence here that $M$. hilpertae and $M$. derbyensis were feeding

476 on the host's hemolymph or tissue, this seems to be the most parsimonious explanation to us.

477 First, parasitized pupae possessed scars which can be interpreted as feedings marks. We consider

478 it most likely that scars represent areas where mites used their chelicera to pinch the ant's cuticle

479 in order to feed on host tissue and/or drink from the excreting hemolymph. Second, we found

480 exuviae of different development stages inside individual pupal cocoons, indicating that the mites 
481 grew by feeding on the ant pupae. Consumption of host tissue/hemolymph is also indicated by

482 the fact that detached mites left behind physical impressions constituting substantial parts of the 483 ants' gasters.

484 In ant-associated Mesostigmata, parasitoidism has only been described in the genus

485 Macrodinychus (Lachaud, Klompen \& Pérez-Lachaud, 2016). The five more extensively studied

486 Marodinychus species (including M. hilpertae and M. derbyensis) seem to share the following

487 key life-history traits (González, Gómez \& Mesa, 2004; Breton, Takaku \& Tsuji, 2006; Krantz,

488 Gómez \& González, 2007; Lachaud, Klompen \& Pérez-Lachaud, 2016): All species seem to

489 fulfill their entire immature development, including larval, proto- and deutonymphal stage, by

490 feeding on individual ant pupa. For this, they seem to pierce the pupal cuticle with their chelicera

491 to consume host tissue and/or to suck host hemolymph leaving behind small, brownish feeding

492 marks. The larvae have well-developed legs and hence seem to be the mobile instar to find

493 suitable hosts, while proto- and deutonymphs are more likely immobile feeding instars.

494 Macrodinychus adults finally occupy a substantial part of the pupa's body. Once removed from

495 the ant, they leave behind a conspicuous cavity, providing visual evidence for a lethal feeding

496 strategy.

497 Parasitism rates of macrodinychid mites - native versus invasive host ants

498 Besides similarities among species, we also detected a notable difference between the

499 Macrodinychus species studied previously and those studied here. The prevalence of infection,

500 measured as the percentage of infected to non-infected host pupae, was markedly lower in $M$.

501 hilpertae and M. derbyensis [approx. 2\% vs. 15\% - 90\% in other Macrodinychus species (see

502 González, Gómez \& Mesa, 2004; Breton, Takaku \& Tsuji, 2006; Krantz, Gómez \& González,

503 2007; Lachaud, Klompen \& Pérez-Lachaud, 2016)]. Various explanations could be responsible

504 for the vastly different parasitism rates among studied macrodinychid mites. For example, the 
505 particular sampling methods or seasonal and spatial differences in parasitoid prevalence could

506 conceivably cause such variation. Another possible cause is that Macrodinychus hilpertae and M.

507 derbyensis have been studied in a native host-parasitoid system, while other Macrodinychus spp.

508 have exclusively been studied in association with invasive ant species. Parasitoids are often a

509 major source of host mortality and intense selection on the host to evolve counter-defenses

510 against parasitoid attacks can be expected (Godfray, 1994). In species drifts across continents,

511 however, local and alien interaction partners have no coevolutionary history (Thompson, 2005;

512 Simberloff, 2013). In such situations, naïve hosts can suffer from extremely high parasitism rates

513 (Kirk, 2003; Prenter et al., 2004; Lymbery et al., 2014), which can, in extreme cases, lead to the

514 decline of local host populations (Holdich \& Reeve, 1991). Invasive ants, in particular, might be

515 predisposed to parasitism by local species due to mass propagation coupled with genetic

516 depletion (Sakai et al., 2001; Holway et al., 2002; Tsutsui \& Suarez, 2003; Lester \& Gruber,

517 2016). In fact, a recent host switch of local Macrodinychus parasitoids to invasive ants has been

518 suggested to be responsible for the high parasitism rates found in M. yonakuniensis (15\%)

519 (Breton, Takaku \& Tsuji, 2006), M. multispinosus (26\%) (Lachaud, Klompen \& Pérez-Lachaud,

520 2016) and M. sellnicki (up to 90\%) (González, Gómez \& Mesa, 2004; Krantz, Gómez \&

521 González, 2007).

\section{Possible counter-adaptations against macrodinychid mites}

523 Hidden inside the pupal silk cocoons, the immature mites studied here are practically invisible to

524 adult host workers. In contrast, once eclosed from the pupal cocoon, adult mites are exposed and

525 thus are accessible for host inspection. Similar to socially integrated species such as the spider

526 Sicariomorpha maschwitzi (Witte 2009; von Beeren et al, 2012) and the silverfish Malayatelura

527 ponerophila (Witte 2009; von Beeren et al, 2011b), adult Macrodinychus spp. were mostly

528 ignored or unnoticed by host ants. Nonetheless, host workers regularly antennated adult 
529 parasitoids and ultimately attacked them, although at a relatively low level. Low levels of

530 aggression towards myrmecophiles are still biologically relevant. For instance, soft bodied

531 myrmecophiles such as the silverfish M. ponerophila were occasionally killed in behavioral

532 assays (Witte et al., 2008; von Beeren et al., 2011b). We interpret the occasional attacks towards

533 Macrodinychus mites as a behavior to fight off the adult parasitoid before host brood become

534 infected with parasitoid larvae. However, Macrodinychus specimens survived these attacks

535 unscathed owing to their protective morphology, embodied by a well-sclerotized cuticle and the

536 possibility to retract all extremities into cuticular cavities (pedofossae) (see Figs. 2, 3). A more

537 efficient host defense might be the ants' behavior following the initial attacks. Macrodinychus

538 spp. were often picked up by workers in laboratory nests and dumped at the ants' refuse site,

539 outside the inner nest part where the parasitoid target, i.e. ant brood, is located. The adult mites

540 were mobile and regularly re-entered the brood chambers in laboratory nests, only to be picked

541 up and dumped at the refuse site again. In addition to this, the frequent emigrations of army ants

542 might represent another counter-measurement to reduce a colony's total fitness loss imposed by

543 parasites and parasitoids (Witte et al., 2008; von Beeren et al., 2011a) because

544 parasites/parasitoids can be left behind at the abandoned nest site (Witte, 2001). Support for this

545 hypothesis comes from an observation during a nest emigration of Leptogenys distinguenda

546 initiated in the laboratory at the field site. We collected three Macrodinychus spp. adults at the

547 abandoned nest site (a $1 \mathrm{~m} \times 1 \mathrm{~m} \times 1 \mathrm{~m}$ plastic box filled with leaf litter), in other words, the

548 emigrated colony shed off these parasitoids.

\section{Conclusions}

550 Parasitoidism and also parasitism of ants by mites is likely more common than hitherto known

551 (Campbell, Klompen \& Crist, 2013; Lachaud, Klompen \& Pérez-Lachaud, 2016) and the cryptic

552 lifestyles of mites inside ant nests has certainly hampered their discovery (Skoracka et al., 2015). 
553 In fact, the species studied here were chance finds that were initially overlooked. It is safe to say

554 that many more macrodinychid mites await scientific discovery (see e.g., Lachaud, Klompen \&

555 Pérez-Lachaud, 2016) and we thus would like to encourage researchers to specifically screen ant

556 brood for these fascinating and rather unexplored parasitoids.

\section{Acknowledgements}

558 AB thanks the Acarology Summer Program 2016 at Ohio State University in Columbus, for the

559 awesome class and in-depth discussions about mites and science. The following people helped to

560 collect samples from L. distinguenda colony emigrations: Deborah Schweinsfest, Magdalena

561 Mair, Sebastian Pohl, Volker Witte, Daniel Schließmann, Max Kölbl, Hannah Kriesell, Stefan

562 Huber, and Sofia Lizon à l'Allemand. We thank Marc Pfitzer who guided the imaging process,

563 Andrea Hilpert who dissected part of the pupal cocoons, and Philipp Hönle for editing the video

564 file. We thank Peter Schwendiger of the Museum of Natural History Geneva and Stefan Friedrich

565 of the Bavarian State Collection of Zoology for a friendly process of specimen loans. Finally, we

566 are particularly thankful to Volker Witte who sadly passed away in 2015. Without his dedication

567 to the study of army ants and their associates, this study would not exist.

\section{References}

569 Anderson M., Gorley RN., Clarke RK. 2008. Permanova+ for Primer: Guide to Software and $570 \quad$ Statistical Methods. Plymouth: Primer-E.

571 Beaulieu F., Dowling APG., Klompen H., De Moraes GJ., Walter DE. 2011. Superorder $572 \quad$ Parasitiformes Reuter, 1909. Zootaxa 3148:123-128.

573 von Beeren C., Hashim R. and Witte V. (2012). The social integration of a myrmecophilous 574 spider does not depend exclusively on chemical mimicry. Journal of Chemical Ecology, 575 38:262-271 
576 von Beeren C., Maruyama M., Hashim R., Witte V. 2011a. Differential host defense against 577 multiple parasites in ants. Evolutionary Ecology 25:259-276. DOI: 10.1007/s10682-010$578 \quad 9420-3$.

579 von Beeren C., Schulz S., Hashim R., Witte V. 2011b. Acquisition of chemical recognition cues 580 facilitates integration into ant societies. BMC Ecology 11:30. DOI: 10.1186/1472-6785$581 \quad 11-30$.

582 Berlese A. 1916. Centuria seconda di Acari nuovi. Redia 12:125-177.

583 Berlese A. 1917. Intorno agli Uropodidae. Redia 13:7-16.

584 Breton JL., Takaku G., Tsuji K. 2006. Brood parasitism by mites (Uropodidae) in an invasive 585 population of the pest-ant Pheidole megacephala. Insectes Sociaux 53:168-171.

586 Buschinger A. 2009. Social parasitism among ants: a review (Hymenoptera: Formicidae). $587 \quad$ Myrmecological News 12:219-235.

588 Campbell KU., Klompen H., Crist TO. 2013. The diversity and host specificity of mites 589 associated with ants: the roles of ecological and life history traits of ant hosts. Insectes $590 \quad$ Sociaux 60:31-41.

591 Donisthorpe HSJK. 1927. The guests of British ants: their habits and life-histories. London: G. $592 \quad$ Routledge and Sons.

593 Eickwort GC. 1990. Associations of mites with social insects. Annual Review of Entomology $594 \quad 35: 469-488$.

595 Evans, GO 1963. Observations on the chaetotaxy of the legs in free-living Gamasina (Acari: 596 Mesostigmata). Bulletin of the British Museum of Natural History, Zoology, 10: 277-303.

597 Evans, GO 1972. Leg chaetotaxy and the classification of the Uropodina (Acari: Mesostigmata). 598 Journal of Zoology, London, 167: 193-206. 
599 Godfray HCJ. 1994. Parasitoids: behavioral and evolutionary ecology. Princeton: Princeton $600 \quad$ University Press.

601 Godfray HCJ. 2004. Parasitoids. Current Biology 14:R456.

602 González V., Gómez VE., Mesa NC. 2004. Observaciones sobre la biología y comportamiento del 603 acaro Macrodinychus sellnicki (Mesostigmata: Uropodidae) ectoparasitoide de la hormiga 604 loca Paratrechina fulva (Hymenoptera: Formicidae). Revista Colombiana de $605 \quad$ Entomologia 30:143-149.

606 Gotwald Jr WH. 1996. Mites that live with army ants: a natural history of some myrmecophilous 607 hitch-hikers, browsers, and parasites. Journal of the Kansas Entomological Society 608 69:232-237.

609 Halliday RB. 2015. Catalogue of genera and their type species in the mite Suborder Uropodina $610 \quad$ (Acari: Mesostigmata). Zootaxa 3972:101-147.

611 Hirschmann W. 1975. Gangsystematik der Parasitiformes Teil 204. Die Gattung Macrodinychus 612 (Berlese, 1917) und die Untergattung Monomacrodinychus novum subgenus 613 (Trichouropodini, Uropodinae). Acarologie. Schriftenreihe für Vergleichende Milbenkunde 21:35-36.

615 Hirschmann W. 1979. Gangsystematik der Parasitiformes. Teil 338. Bestimmbare Uropodiden616 Arten der Erde (ca. 1200 Arten), geordnet nach Gangsystem Hirschmann 1979 und nach Adulten-Gruppen (Stadien, Heimatländer, Synonyma, Literatur). Acarologie. Schriftenreihe fur Vergleichende Milbenkunde 26:15-57.

619 Hirschmann W. 1983. Gangsystematik der Parasitiformes Teil 430. Stadein von 4 neuen 620 Uropodiden - Arten aus Zaire, Vietnam und Tanganyika. Acarologie. Schriftenreihe für Vergleichende Milbenkunde 30:73-77. 
622 Holdich DM., Reeve ID. 1991. Distribution of freshwater crayfish in the British Isles, with 623 particular reference to crayfish plague, alien introductions and water quality. Aquatic 624 Conservation: Marine and Freshwater Ecosystems 1:139-158.

625 Hölldobler B., Wilson EO. 1990. The Ants. Cambridge, MA: Harvard University Press.

626 Holway DA., Lach L., Suarez AV., Tsutsui ND., Case TJ. 2002. The causes and consequences of 627 ant invasions. Annual Review of Ecology and Systematics 33:181-233.

628 Hughes DP., Pierce NE., Boomsma JJ. 2008. Social insect symbionts: Evolution in homeostatic 629 fortresses. Trends in Ecology \& Evolution 23:672-677. DOI: 10.1016/j.tree.2008.07.011.

630 Janssen R., Witte V. 2002. Allopeas myrmekophilos n. sp., the first snail reported as living in 631 army ant colonies (Gastropoda: Pulmonata: Subulinidae). Archiv für Molluskenkunde 632 $131: 211-215$.

Kirk RS. 2003. The impact of Anguillicola crassus on European eels. Fisheries Management and 634 Ecology 10:385-394.

635 Kistner DH. 1979. Social and evolutionary significance of social insect symbionts. In: Hermann 636 HR ed. Social Insects. New York, NY: Academic Press, 339-413.

637 Kistner DH. 1982. The social insects' bestiary. In: Hermann HR ed. Social Insects. New York, $638 \quad$ NY: Academic Press, 1-244.

639 Kistner DH. 1989. New genera and species of Aleocharinae associated with ants of the genus 640 Leptogenys and their relationships (Coleoptera: Staphylinidae; Hymenoptera: $641 \quad$ Formicidae). Sociobiology 15:209-323.

642 Kistner DH., Witte V., Maschwitz U. 2003. A new species of Trachydonia (Coleoptera: 643 Staphylinidae, Aleocharinae) from Malaysia with some notes on its behavior as a guest of 644 Leptogenys (Hymenoptera: Formicidae). Sociobiology 42:381-389.

645 Kontschán J. 2011. Notes on the family Macrodinychidae (Acari: Uropodina) with description of 646 two new species. Journal of Natural History 45:1619-1636. 
647 Kontschán J. 2017. Macrodinychus tanduk sp. nov., an unusual new macrodinychid species from 648 Sumatra, Indonesia (Mesostigmata Uropodina), with notes on the Macrodinychidae fam. 649 nov. Systematic \& Applied Acarology 22:1267-1276.

650 Krantz GW. 1962. Descriptions of three myrmecophilous Macrochelidae (Acarina: 651 Mesostigmata) from Panama, British Guiana and the British West Indies. Journal of the $652 \quad$ Kansas Entomological Society 35:349-357.

653 Krantz GW., Gómez LA., González VE. 2007. Parasitism in the Uropodina: a case history from 654 Colombia. In: Morales-Malacara JB, Behan-Pelletier V, Ueckermann E, Perez T, Estrada655 Venegas E, Badii M eds. Acarology XI: Proceedings of the International Congress. 656 México City: Instituto de Biologia and Facultad de Ciencias, Universidad Nacional 657 Autónoma de México, 29-38.

658 Lachaud J-P., Klompen H., Pérez-Lachaud G. 2016. Macrodinychus mites as parasitoids of 659 invasive ants: an overlooked parasitic association. Scientific Reports 6:29995.

660 Lester PJ., Gruber MA. 2016. Booms, busts and population collapses in invasive ants. Biological 661 Invasions 18:3091-3101.

662 Lymbery AJ., Morine M., Kanani HG., Beatty SJ., Morgan DL. 2014. Co-invaders: the effects of 663 alien parasites on native hosts. International Journal for Parasitology: Parasites and $664 \quad$ Wildlife 3:171-177.

665 Maruyama M., von Beeren C., Hashim R. 2010. Aleocharine rove beetles (Coleoptera: 666 Staphylinidae) associated with Leptogenys Roger, 1861 (Hymenoptera: Formicidae) I. 667 Review of three genera associated with L. distinguenda (Emery, 1887) and L. mutabilis 668 (Smith, 1861). ZooKeys:47-60.

669 Maruyama M., von Beeren C., Witte V. 2010. Aleocharine rove beetles (Coleoptera, 670 Staphylinidae) associated with Leptogenys Roger, 1861 (Hymenoptera, Formicidae) II. 
671 Two new genera and two new species associated with L. borneensis Wheeler, 1919. $672 \quad$ ZooKeys 59:61.

673 Maschwitz U., Steghaus-Kovac S. 1991. Individualismus versus Kooperation - Gegensätzliche 674 Jagd- und Rekrutierungsstrategien bei tropischen Ponerinen (Hymenoptera: Formicidae). $675 \quad$ Naturwissenschaften 78:103-113.

676 Maschwitz U., Steghaus-Kovac S., Gaube R., Hänel H. 1987. Eine Treiberameise in der 677 Unterfamilie Ponerinae: Erste Untersuchungen zur Biologie von Leptogenys sp. 1 nahe $L$. 678 mutabilis. IUSSI, 11. Tag. Deutschspr. Sekt:24.

679 Maschwitz U., Steghaus-Kovac S., Gaube R., Hänel H. 1989. A South East Asian ponerine ant of 680 the genus Leptogenys (Hym., Form.) with army ant life habits. Behavioral Ecology and $681 \quad$ Sociobiology 24:305-316.

682 Mendes LF., von Beeren C., Witte V. 2011. Malayatelura ponerophila-a new genus and species 683 of silverfish (Zygentoma, Insecta) from Malaysia, living in Leptogenys army-ant colonies 684 (Formicidae). Deutsche Entomologische Zeitschrift 58:193-200.

685 Ott R., von Beeren C., Hashim R., Witte V., Harvey MS. 2015. Sicariomorpha, a new 686 myrmecophilous goblin spider genus (Araneae, Oonopidae) associated with Asian army $687 \quad$ ants. American Museum Novitates 3843:1-14.

688 Parker J. 2016. Myrmecophily in beetles (Coleoptera): evolutionary patterns and biological 689 mechanisms. Myrmecological News 22:65-108.

690 Prenter J., MacNeil C., Dick JT., Dunn AM. 2004. Roles of parasites in animal invasions. Trends 691 in ecology \& evolution 19:385-390.

692 Rettenmeyer CW. 1961. Arthropods associated with Neotropical army ants with a review of the 693 behavior of these ants (Arthropoda; Formicidae: Dorylinae). Lawrence: University of $694 \quad$ Kansas. 
695 Sakai AK., Allendorf FW., Holt JS., Lodge DM., Molofsky J., With KA., Baughman S., Cabin 696 RJ., Cohen JE., Ellstrand NC., others 2001. The population biology of invasive species. 697 Annual review of ecology and systematics 32:305-332.

698 Simberloff D. 2013. Invasive species: what everyone needs to know. New York, NY: Oxford $699 \quad$ University Press.

700 Skoracka A., Magalhaes S., Rector BG., Kuczyński L. 2015. Cryptic speciation in the Acari: a 701 function of species lifestyles or our ability to separate species? Experimental and Applied 702 Acarology 67:165-182.

703 Thompson JN. 2005. The Geographic Mosaic of Coevolution. Chicago: University Of Chicago $704 \quad$ Press.

705 Tsutsui ND., Suarez AV. 2003. The colony structure and population biology of invasive ants. $706 \quad$ Conservation biology 17:48-58.

707 Walter DE., Krantz GW. 2009. Collecting, rearing, and preparing specimens. A manual of $708 \quad$ Acarology 3:83-96.

709 Walter DE., Proctor HC. 1999. Mites: ecology, evolution and behaviour. Wallingford, UK: CABI.

710 Witte V. 2001. Organisation und Steuerung des Treiberameisenverhaltens bei südostasiatischen 711 Ponerinen der Gattung Leptogenys. Dissertation, Johann Wolfgang Goethe Universität, $712 \quad$ Frankfurt am Main.

713 Witte V., Foitzik S., Hashim R., Maschwitz U., Schulz S. 2009. Fine tuning of social integration 714 by two myrmecophiles of the ponerine army ant Leptogenys distinguenda. Journal of $715 \quad$ Chemical Ecology 2009, 35:355-367.

716 Witte V., Hänel H., Weissflog A., Rosli H., Maschwitz U. 1999. Social integration of the 717 myrmecophilic spider Gamasomorpha maschwitzi (Araneae: Oonopidae) in colonies of 718 the South East Asian army ant, Leptogenys distinguenda (Formicidae: Ponerinae). $719 \quad$ Sociobiology 34:145-159. 
720 Witte V., Janssen R., Eppenstein A., Maschwitz U. 2002. Allopeas myrmekophilos (Gastropoda, 721 Pulmonata), the first myrmecophilous mollusc living in colonies of the ponerine army ant 722 Leptogenys distinguenda (Formicidae, Ponerinae). Insectes Sociaux 49:301-305.

723 Witte V., Leingärtner A., Sabaß L., Hashim R., Foitzik S. 2008. Symbiont microcosm in an ant 724 society and the diversity of interspecific interactions. Animal Behaviour 76:1477-1486. 725 DOI: 10.1016/j.anbehav.2008.05.010.

726 Witte V., Maschwitz U. 2000. Raiding and emigration dynamics in the ponerine army ant 727 Leptogenys distinguenda (Hymenoptera, Formicidae). Insectes Sociaux 47:76-83.

728 Witte V., Maschwitz U. 2002. Coordination of raiding and emigration in the ponerine army ant 729 Leptogenys distinguenda (Hymenoptera: Formicidae: Ponerinae): a signal analysis. $730 \quad$ Journal of Insect Behavior 15:195-217.

731 Wunderlich J. 1994. Beschreibung bisher unbekannter Spinnenarten und -gattungen aus Malaysia 732 und Indonesien (Arachnida: Araneae: Oonopidae, Tetrablemmidae, Telemidae, Pholcidae, Linyphiidae, Nesticidae, Theridiidae und Dictynidae). Beiträge zur Araneologie 4:559579. 
735 Figure 1. Host pupa infected with Macrodinychus parasitoid. Pupae were collected during

736 colony emigrations of Leptogenys distinguenda. Pupal cocoons are opaque but become

737 transparent in ethanol (white arrow). The highlighted pupa is infected with Macrodinychus

738 hilpertae.

739 Figure 2. Macrodinychus (Monomacrodinychus) hilpertae holotype. (A) Dorsal, (B) lateral,

740 and (C) ventral view of the Macrodinychus hilpertae holotype. Scale bars are $250 \mu \mathrm{m}$.

741 Figure 3. Macrodinychus (Monomacrodinychus) derbyensis holotype. (A) Dorsal, (B) lateral,

742 and (C) ventral view of the Macrodinychus derbyensis holotype. Scale bars are $325 \mu \mathrm{m}$.

743 Figure 4. Macrodinychus hilpertae attached to ant pupae. (A, D) Deutonymphs of $M$.

744 hilpertae (A) attached to and (D) detached from developing ant pupae (silk cocoon removed). (B,

745 E) Respective ant specimens with mites removed exposing the abnormal intrusion in the ants'

746 gasters and the brownish scars. Larval exuviae of $M$. hilpertae are still sticking to the ants

747 (dashed square). (C, F) Enlarged view of the larval exuviae. The cheliceral cuticles are still

748 sticking to the ant's wound. Scale bars are $1 \mathrm{~mm}$ except for images $\mathrm{c}$ and $\mathrm{f}$ where it is $0.1 \mathrm{~mm}$.

749 Figure 5. Ant-symbiont interactions and ant aggression towards symbionts. (A) Nonmetric-

750 multidimensional scaling (NMDS) plot visualizes the differences in behavioral interactions

751 between host ants and seven symbiont species. Each data point represents approx. 50 encounters

752 of an individual symbiont with host ants. Length and direction of arrows visualize the

753 contribution of behavioral categories to data separation. For clarity, the origin of arrows is not

754 centered in the plot. 'Stress' is a quality measure of the NMDS. (B) Aggressive behaviors of ants

755 towards symbionts. Depicted is the aggression index (AI), which is the proportion of aggressive

756 behaviors (sum of chased, snapped, and stung) towards symbiont specimens relative to their total 
757 number of interactions (approx. 50 for all specimens). Different letters depict significant 758 differences $(\mathrm{p}<0.05$; PERMANOVA pairwise tests $)$. 


\section{Figure 1 (on next page)}

Host pupa infected with Macrodinychus parasitoid.

Pupae were collected during colony emigrations of Leptogenys distinguenda. Pupal cocoons are opaque but become transparent in ethanol (white arrow). The highlighted pupa is infected with Macrodinychus hilpertae. 


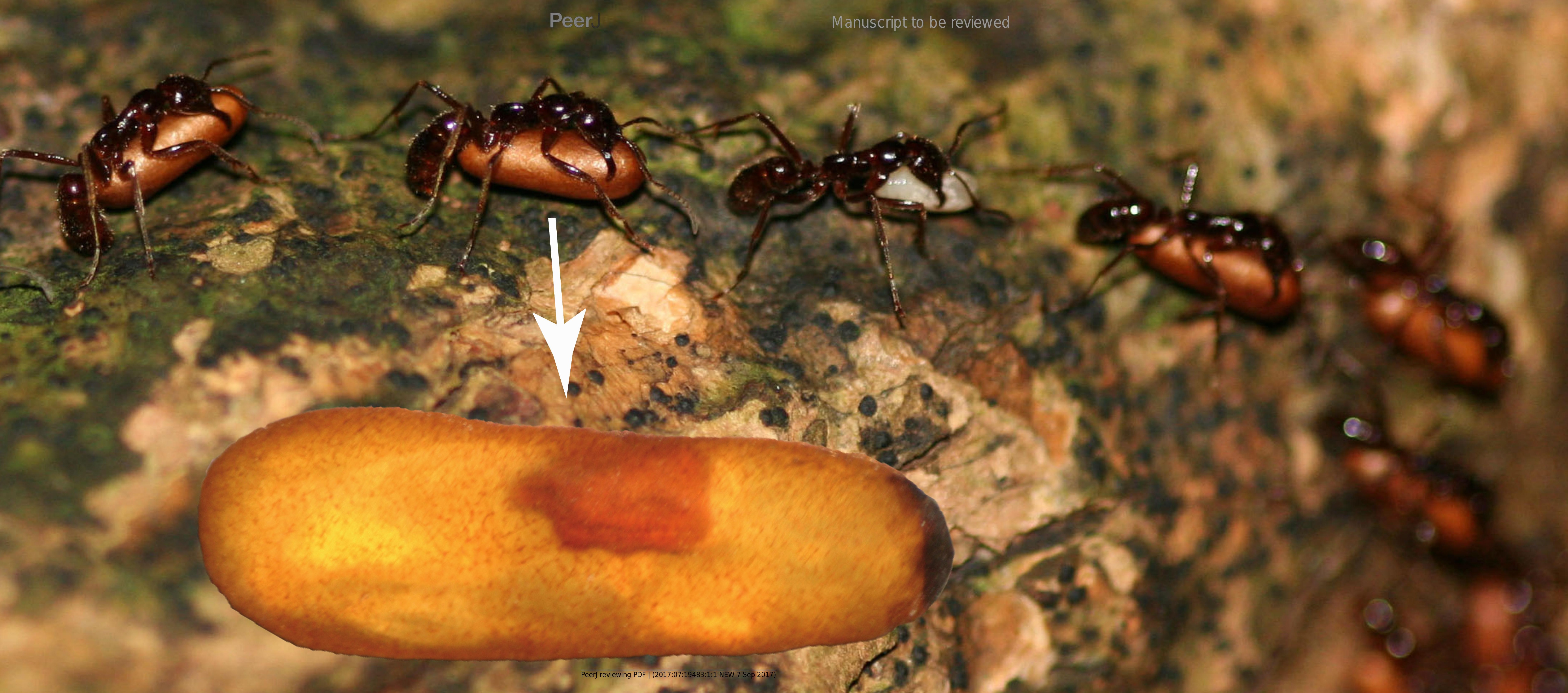


Figure 2 (on next page)

Macrodinychus (Monomacrodinychus) hilpertae holotype.

(A) Dorsal, (B) lateral, and (C) ventral view of the Macrodinychus hilpertae holotype. Scale bars are $250 \mu \mathrm{m}$. 
$A$

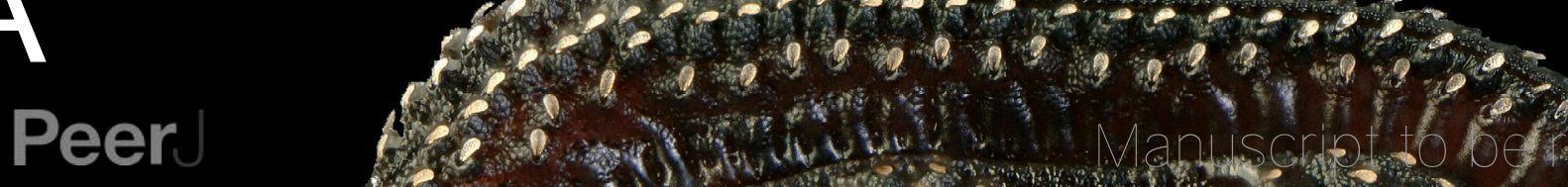
3. - 1) Manuscrint to belreviewed

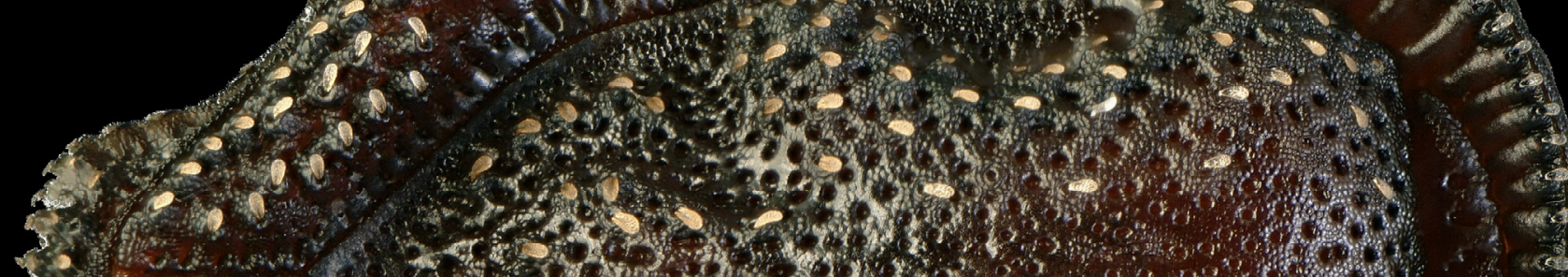

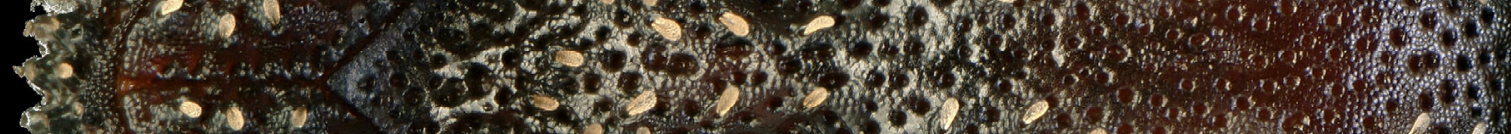

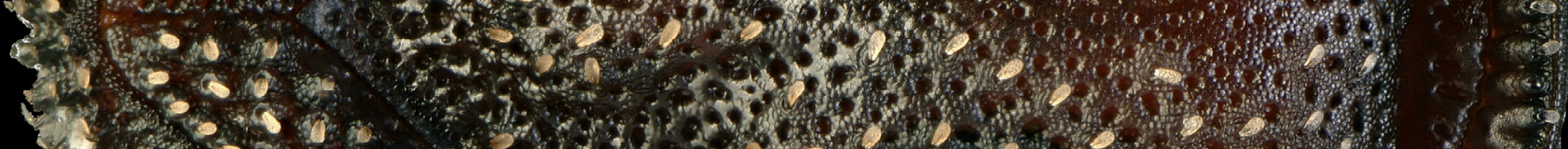

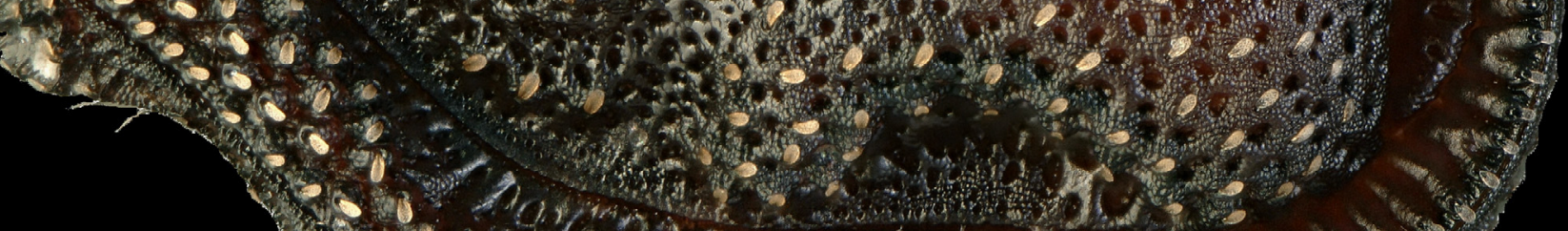

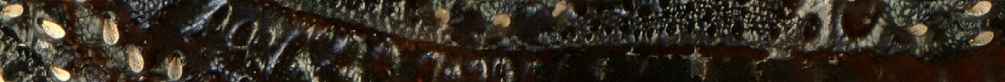

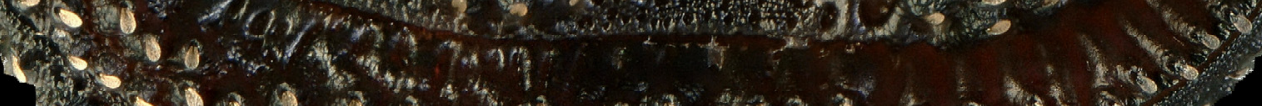

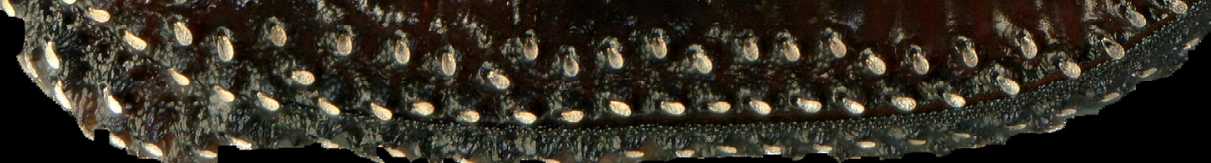

B
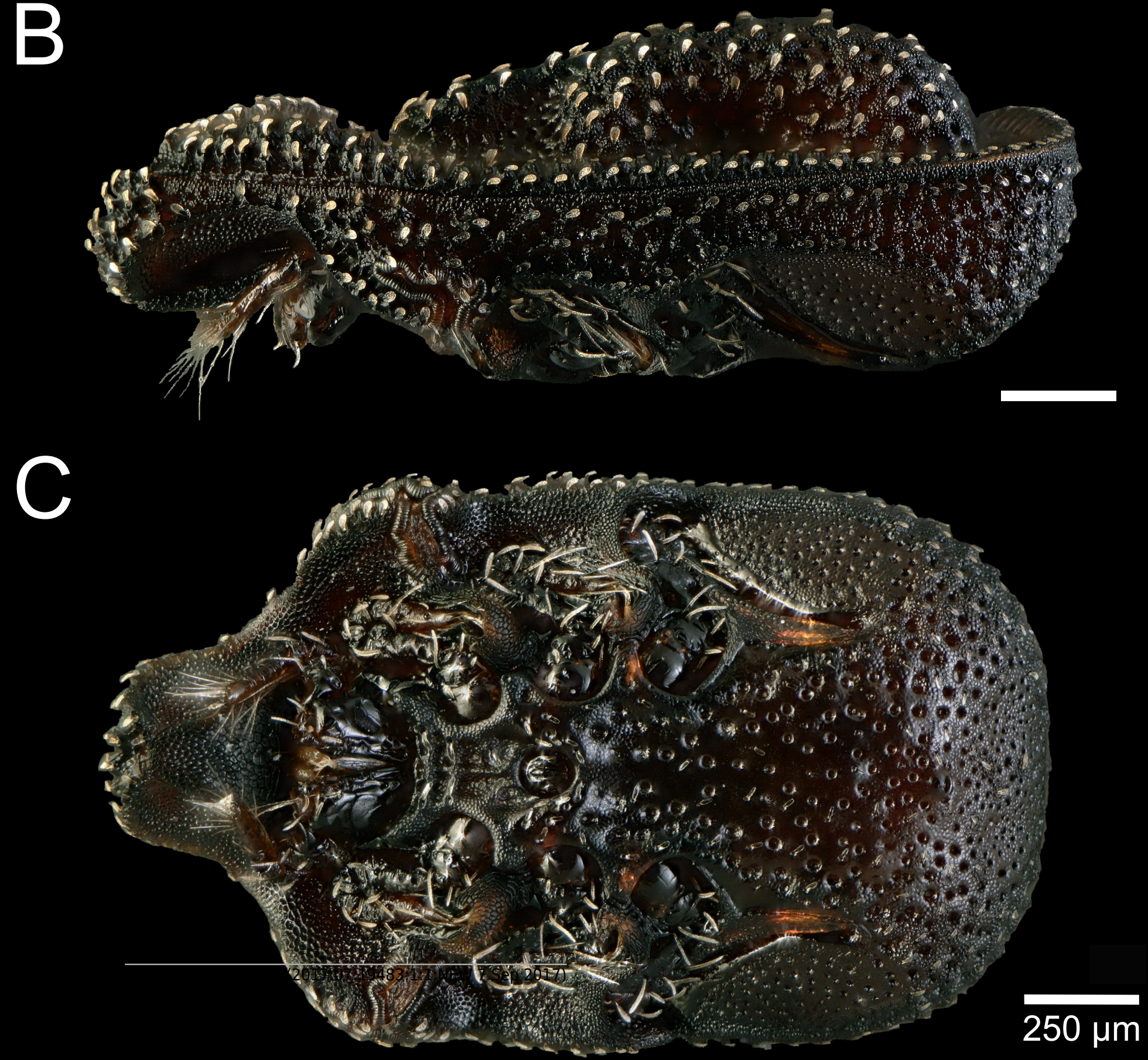


\section{Figure 3 (on next page)}

Macrodinychus (Monomacrodinychus) derbyensis holotype.

(A) Dorsal, (B) lateral, and (C) ventral view of the Macrodinychus derbyensis holotype. Scale bars are $325 \mu \mathrm{m}$. 
A

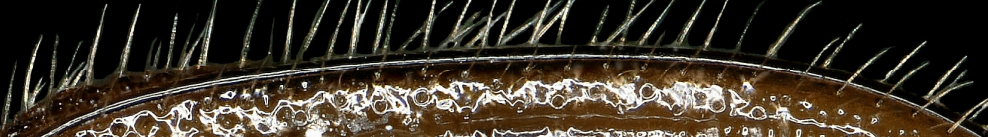

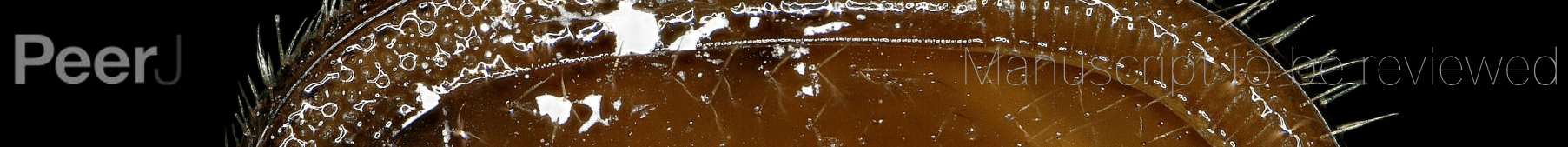

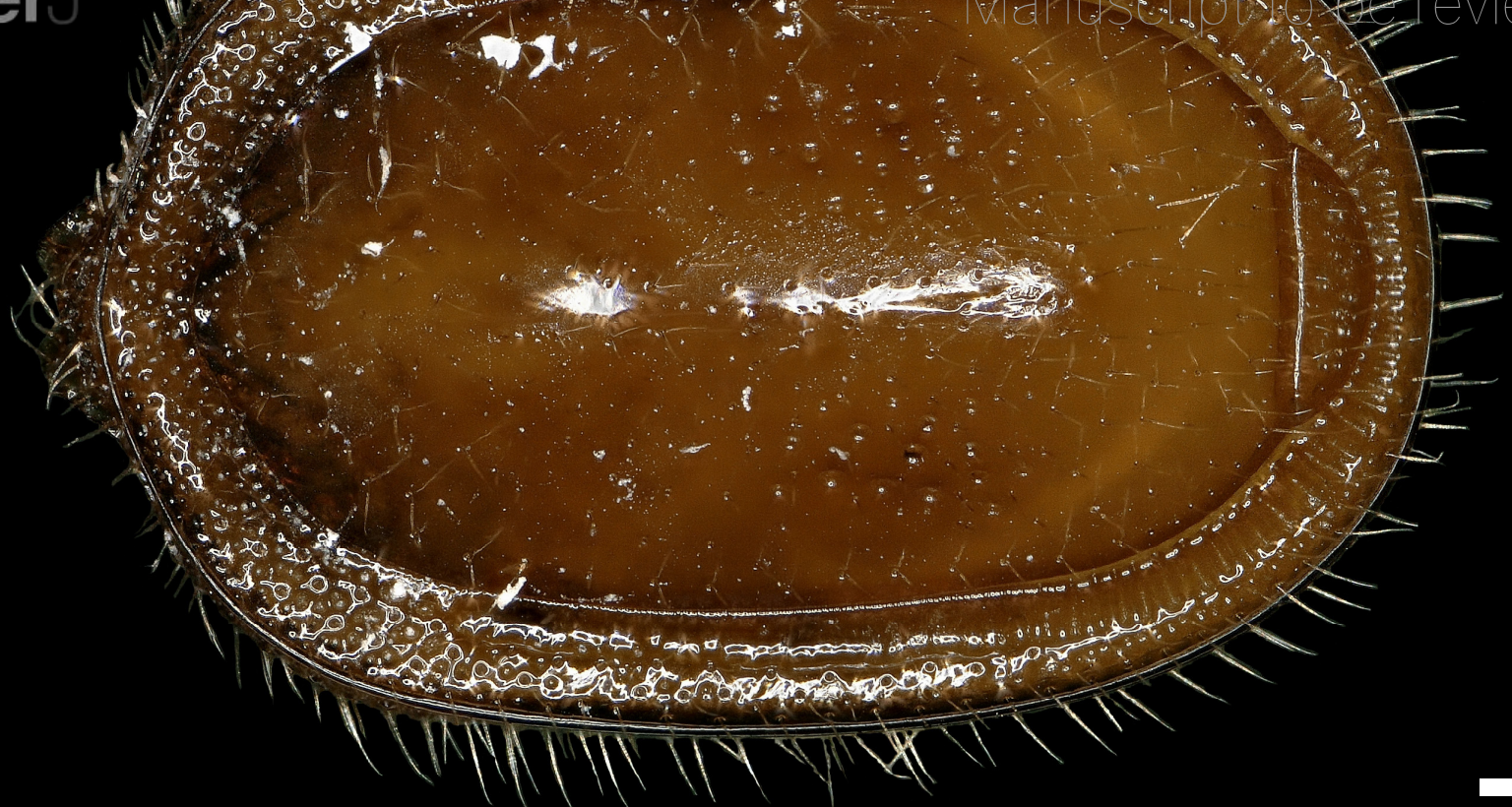

B
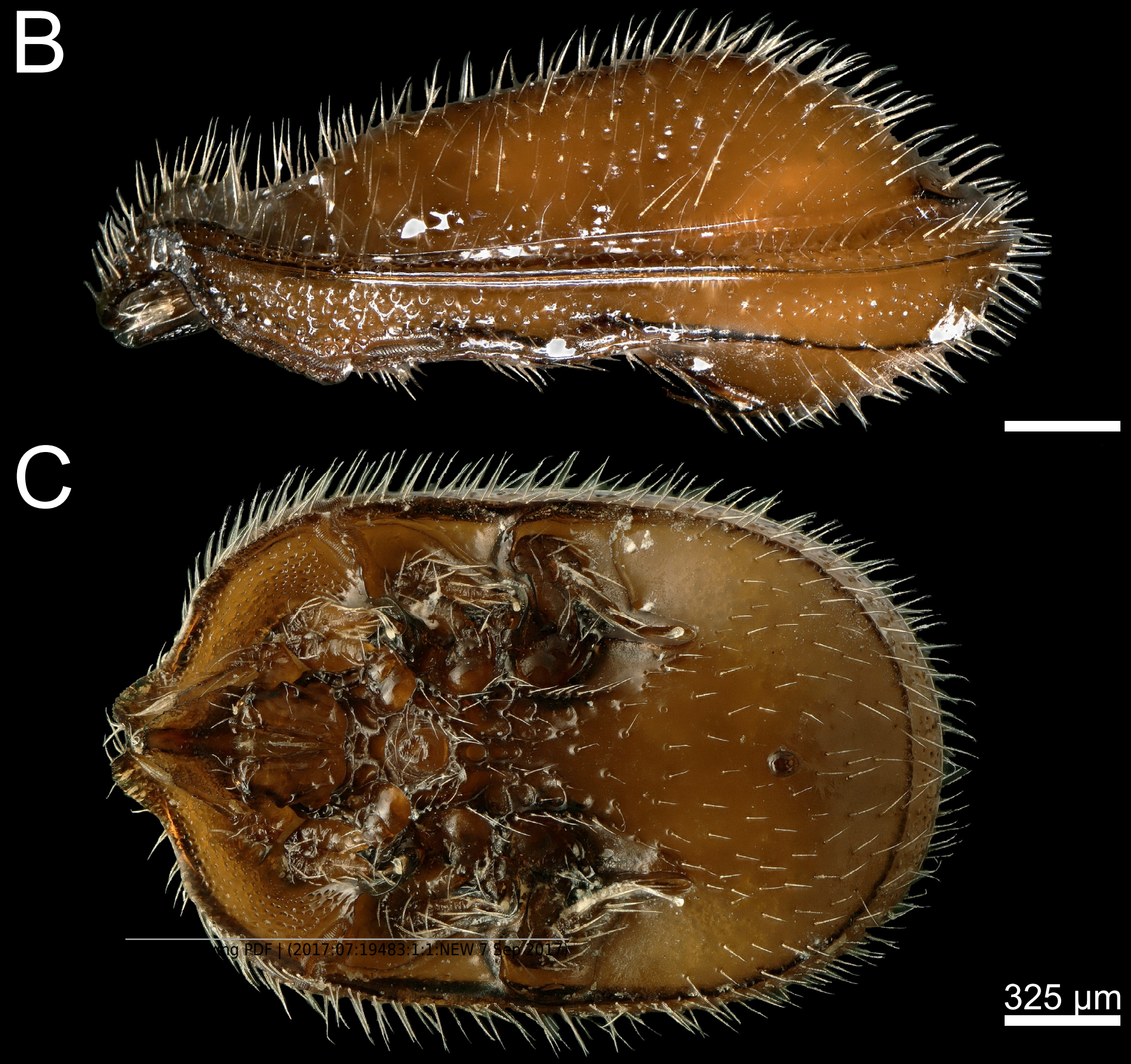
Figure 4 (on next page)

Macrodinychus hilpertae attached to ant pupae.

(A, D) Deutonymphs of M. hilpertae (A) attached to and (D) detached from developing ant pupae (silk cocoon removed). (B, E) Respective ant specimens with mites removed exposing the abnormal intrusion in the ants' gasters and the brownish scars. Larval exuviae of $M$. hilpertae are still sticking to the ants (dashed square). (C, F) Enlarged view of the larval exuviae. The cheliceral cuticles are still sticking to the ant's wound. Scale bars are $1 \mathrm{~mm}$ except for images $\mathrm{c}$ and $\mathrm{f}$ where it is $0.1 \mathrm{~mm}$. 


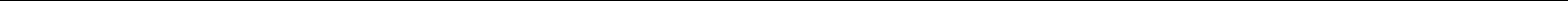




\section{Figure 5 (on next page)}

Ant-symbiont interactions and ant aggression towards symbionts.

(A) Nonmetric-multidimensional scaling (NMDS) plot visualizes the differences in behavioral interactions between host ants and seven symbiont species. Each data point represents approx. 50 encounters of an individual symbiont with host ants. Length and direction of arrows visualize the contribution of behavioral categories to data separation. For clarity, the origin of arrows is not centered in the plot. 'Stress' is a quality measure of the NMDS. (B) Aggressive behaviors of ants towards symbionts. Depicted is the aggression index (Al), which is the proportion of aggressive behaviors (sum of chased, snapped, and stung) towards symbiont specimens relative to their total number of interactions (approx. 50 for all specimens). Different letters depict significant differences $(p<0.05$; PERMANOVA pairwise tests). 


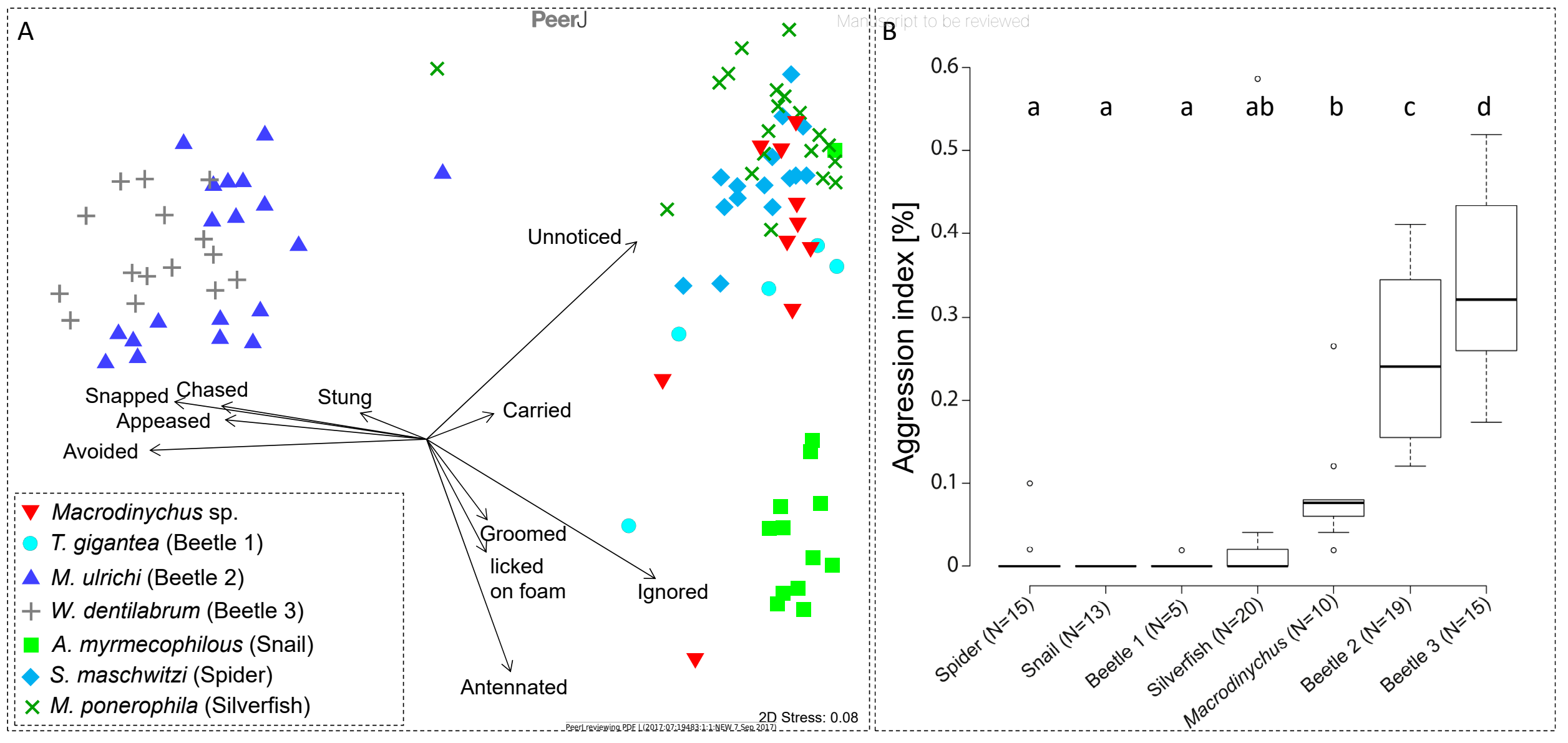

